\title{
Interaction between mealybugs (Pseudococcidae) and coffee plants
}

\author{
Lenira Viana Costa Santa-Cecília ${ }^{1}$ (iD), Kethullyn Henrique Silva ${ }^{1}$ (D)
}

${ }^{1}$ Empresa de Pesquisa Agropecuária de Minas Gerais/EPAMIG Sul, Lavras, MG, Brasil

Contact authors: lenira.santa.cecilia@gmail.com, keth-94@hotmail.com

Received in December 19, 2019 and approved July 29, 2020

\begin{abstract}
Mealybugs, Planococcus citri (Risso) and Planococcus minor (Maskell) (Hemiptera: Pseudococcidae) are able to colonize several plants, such as coffee (Coffea spp.), where may impair their production. Despite attacking many plants, frequent outbreaks are only found in certain plants. In this work, we tested the hypothesis that $P$. citri and $P$. minor show a better performance, i.e., greater longevity and higher reproductive rate, as well as higher survival in a given coffee species and it exists preference for volatiles of certain coffee species. We studied in the laboratory the food preference of these mealybugs through a free choice test and their development and reproduction in Coffea arabica L. cv. Mundo Novo-IAC-379-19 and Coffea canephora (Pierre \& Froenher) cv. Conilon 213. The responsiveness of these insects to the volatiles emitted by these coffee plants was analyzed using an olfactometer. The data showed that mealybugs preferred Conilon coffee plants over the Mundo Novo and, despite completing their development in both of them, most of the biological evaluated parameters were affected by the host species. In the olfactometer assays, the volatiles emitted by the coffee plants cv. Mundo Novo and Conilon were equally attractive to these mealybugs. It is concluded that, although there is no discrimination of odors between coffee plants, Mundo Novo and Conilon, both species of mealybugs show food preference for Conilon, having their development and reproduction favored in these plants.
\end{abstract}

Key words: Coffea spp.; Food preference; Olfactory responses; Performance; White mealybug.

\section{INTRODUCTION}

The citrus mealybug, Planococcus citri (Risso) and the passionvine mealybug Planococcus minor (Maskell) (Hemiptera: Pseudococcidae) are important pests to the coffee crop in Brazil, attacking Coffea arabica L. and Coffea canephora (Pierre \& Froenher). Nymphs and adult females of both species colonize the aerial part of plants, mainly the flower and fruit buds, as well as new shoots, and as a result sap sucking, fruits dry and fall, limiting crop yield (Santa-Cecília; Souza, 2014; Santa-Cecília et al., 2020).

These mealybugs are capable of colonizing various host plants, belonging to 84 and 73 botanical families for $P$. citri and for $P$. minor respectively (García Morales et al., 2016). Despite colonizing several plant species, outbreaks are more frequent in certain hosts, which can be attributed to several factors, including biological performance (Santa-Cecília et al., 2018).

This performance is related to the reproductive success depending on their ability to avoid and/or overcome the plant defenses present at the cuticle, epidermis, mesophyll and phloem levels. As an example, plant surface presents hair, thorns, trichomes and thick cuticles, which may exert some action preventing mealybug settling (Renard, 1993; Le Rü et al., 1995; Santa-Cecília; Prado; Souza, 2016).

Food quality and quantity are fundamental for insect performance (Slansky; Rodriguez, 1987; Parra, 1991; Awmack; Leather, 2002). Ingested food directly influences the distribution and abundance of insects, affecting biological parameters such as fecundity, longevity, development and behavior (Silveira-Neto et al., 1976). As phloem sap sucking insect, mealybugs (Pseudococcidae) are greatly influenced by the quality of the phloem sap (Santa-Cecília; Prado; Souza, 2016).

Considering the importance of coffee culture for the economy of Brazil, and the frequency of attacks and damages of $P$. citri and $P$. minor to these plants, the objective of this work was to know some aspects about the colonization and establishment of these insects in $C$. arabica and $C$. canephora. We tested the hypothesis that $P$. citri and $P$. minor show a better performance, i.e., greater longevity, higher reproductive rate, as well as higher survival in a given coffee species and have an olfactory preference for volatiles in between coffee species.

We used the choice test to evaluate the food preference that, involves morphological characteristics of plant tissues such as the cuticle, cells, intercellular space, and phloem sap composition. The development, survival, and fecundity were evaluated on both coffee species considering that different hosts may affect parameters of their life history (Amarasekare et al., 2008; Qin et al., 2011; Tanga et al., 2013; Costa et al., 2016; Sousa et al., 2018). Attractiveness and repellency were tested using olfactometry (SantaCecília et al., 2018).

With the results obtained, a better understanding is expected of the interaction of these mealybugs and coffee trees, which could explain the most frequent outbreaks of these pests on certain coffee species. 


\section{MATERIAL AND METHODS}

Mealybugs: $P$. citri was collected in coffee trees and $P$. minor from cocoa plants (Theobroma cacao L.). Insect rearing was established in laboratory on pumpkins (Cucurbita maxima L.) cv Cabotchá (Lepage, 1942), kept in Flanders batteries $(0.42 \times 0.63 \times 0.39 \mathrm{~m})$ in total scotophase under $25 \pm 1^{\circ} \mathrm{C}$ and $70 \pm 10 \% \mathrm{RH}$, according to the methodology described by Santa-Cecília, Prado and Oliveira (2013).

Plants: The treatments consisted of leaves taken from two coffee species, C. arabica cv. Mundo Novo-IAC 379-19 and $C$. canephora cv. Conilon 213. Leaves free from pests, diseases and injuries were collected in the middle third of the coffee plants, approximately four years old, growing at the Coffee Culture Studies Center - NECAF, Campus of the Federal University of Lavras, MG.

Choice test for nymphal food preference: The free choice test was conducted to determine the food preference of mealybugs. The arena consisted of a Petri dish $(0.15 \mathrm{~m}$ diameter $)$ containing a filter paper $(0.05 \mathrm{~m}$ diameter $)$ in the center and both coffee-leaf discs ( $0.05 \mathrm{~m}$ diameter) kept on a layer of $1 \%$ agar with the abaxial surface facing up. Ten third instar nymphs of each mealybug species, were taken from the rearing and fasted for one hour. Soon after, the insects were released in the middle placed on the circle of filter paper (Correa; Souza; Santa-Cecília, 2008; Santa-Cecília; Prado; Oliveira, 2013). So, both mealybugs species were allowed to choose between Conilon 213 and Mundo Novo leaves.

The plates were sealed with polyvinyl chloride plastic film (PVC) to prevent the mealybugs from escaping, kept at $25 \pm 1^{\circ} \mathrm{C}, 70 \pm 10 \% \mathrm{RH}$ and covered with black fabric to avoid possible phototropic effect. The evaluations were performed at 24, 48 and 72 hours, counting the number of mealybugs present on each leaf substrate. Mealybugs found outside leaf discs (on agar and/or paper circle) were not counted. Results obtained at 72 hours of exposure were considered as the definitive preference.

A completely randomized experimental design was adopted for each bioassay, with two treatments (Mundo Novo - IAC 379-19 and Conilon 213) and ten replications, making a total of 100 nymphs for each mealybug species.

Nymphal development and reproduction of mealybugs: Newly hatched nymphs were placed on leaf discs of both hosts (abaxial surface) kept on a layer of $1 \%$ agar $(0.005 \mathrm{~m})$ in Petri dishes ( $0.05 \mathrm{~m}$ diameter). These Petri dishes were sealed with PVC plastic film to prevent mealybugs from escaping and placed in two climate chambers at $25 \pm 1^{\circ} \mathrm{C}, 70 \pm 10 \% \mathrm{RH}$ and scotophase.

Nymphal development was monitored daily until they reached adulthood, using a stereomicroscope (30x). Soon after, couples were formed by placing a male, still in the cocoon with a female in Petri dishes (Santa-Cecília; Prado; Oliveira, 2013).
Nymphal period, mortality and the number of viable eggs (considering the number of nymphs emerged) were recorded.

The experimental design was completely randomized, using two treatments (Mundo Novo-IAC 379-19 and Conilon 213) and each Petri dish was considered a replicate. Ninety replicates were performed for each treatment and mealybug specie. Only females were considered for this analysis.

Olfactory response: The olfactory response of $P$. citri and $P$. minor mealybugs was studied using a four-arms olfactometer with purified air flow (modified from Vet et al., 1983).

The experiments consisted of leaf odors of Mundo NovoIAC 379-19 and Conilon 213 for each mealybug species, kept inside a $400 \mathrm{cc}$ glass container, which were randomly placed on the olfactometer. Two-arms were used for each odor. Air flux was calibrated to $1.2 \mathrm{~L} \cdot \mathrm{min}^{-1}$ so each arm received $0.3 \mathrm{~L} \cdot \mathrm{min}^{-1}$ of air. A stream of purified air carried the volatiles emitted by the coffee leaves to the center of the arena, where mealybug nymphs were released and exposed to these odors for 15 minutes. Thirty fasting nymphs (first instar) of each species were tested. A choice for an odor was defined when the insect surpassed a mark located at $0.02 \mathrm{~m}$ from the releasing point toward one arm. At the end of 15 minutes the arm choice was computed and considered as a definitive choice. The time of permanence in each arm of olfactometer was also registered (Santa-Cecília et al., 2018).

After 10 tests, the leaves were replaced and the odor tubes were washed with detergent, rinsed in running water and cleaned with $70 \%$ alcohol to avoid possible contamination in subsequent tests. The tests were conducted in an environmental room without external interference and visual stimulation.

Data analysis: The Chi-Square test $\left(\chi^{2}\right)$ was used in the choice test and the final choice the olfactometry, considering the observed and expected frequencies. Data from nymphal mortality (\%) was analyzed by the Chi square test $\left(\chi^{2}\right)$. The Student test was used for the duration of the nymphal period, number of viable eggs/female and the permanence time.

We also recorded the number of nymphs that did not respond to odors and remained in the neutral zone of the olfactometer, which were considered "non-responsive".

\section{RESULTS AND DISCUSSION}

Free choice - P. citri showed a preference for Conilon coffee leaves within 24 hours, while for $P$. minor this preference occurred within 48 hours. Although they settled on both coffee species, they showed preference for Conilon. At 72 hours, about $70 \%$ and $62 \%$ of the $P$. citri and $P$. minor nymphs, respectively, were found on Conilon (Figure 1).

Development and reproduction of mealybugs: Mortality, nymphal period and oviposition of P. citri were influenced by the food substrate, presenting higher mortality, longer nymphal development and fewer eggs/female on $C$. arabica (Table 1). 


\section{Planococcus citri}

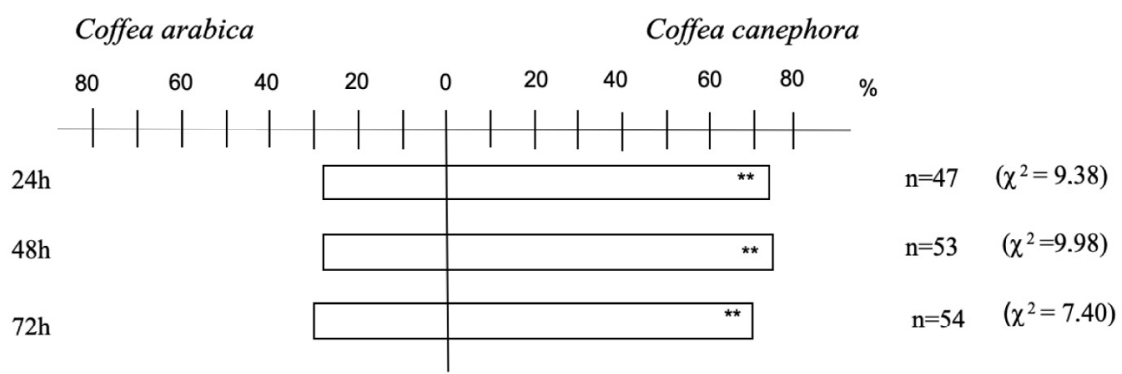

Planococcus minor

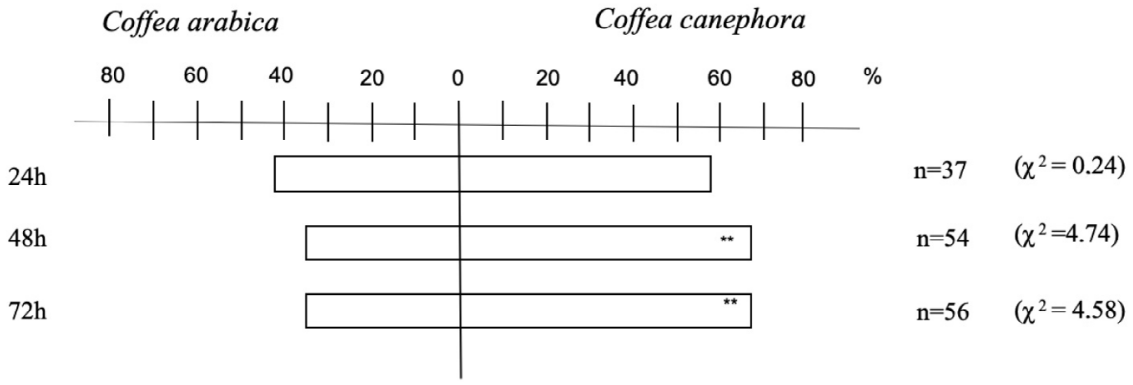

Figure 1: Free choice test of Planococcus citri and Planococcus minor nymphs in leaves of Coffea arabica cv. Mundo Novo-IAC 379-19 versus Coffea canephora cv. Conilon 213. Differences according to the $X^{2}$ test with $1 \mathrm{~g} . \mathrm{I}(\mathrm{p}=3.84)(n=$ number of insects with choice).

Table 1: Biological parameters of Planococcus citri on leaves of coffee species $\left(25 \pm 1^{\circ} \mathrm{C}, 70 \pm 10 \% \mathrm{RH}\right.$, total scotophase).

\begin{tabular}{cccc}
\hline Hosts & Nymph mortality $(\%)$ & Female nymph period (days) & Number of viable eggs/fertile female \\
\hline \multirow{2}{*}{ Coffea arabica cv. Mundo Novo } & $85.7 \mathrm{~A}$ & $34.3 \pm 1.9 \mathrm{~A}$ & $131.3 \pm 17.6 \mathrm{~B}$ \\
$(\mathrm{n}=7)$ & $(\mathrm{n}=7)$ & $176.0 \pm 7.8 \mathrm{~A}$ \\
Coffea canephora cv. Conilon & $56.3 \mathrm{~B}$ & $24.4 \pm 1.1 \mathrm{~B}$ & $(\mathrm{n}=21)$ \\
\hline \multirow{2}{*}{ p value } & $(\mathrm{n}=48)$ & $\leq 49)$ & 0.01 \\
& 0.003 & $(\mathrm{n}=21)$ & (Student)
\end{tabular}

Means followed by different letters in columns differ from each other by the $\chi^{2}$ and Student test. $\mathrm{n}=$ number of observed insects.

Only survival of $P$. minor nymphs was affected by the host, showing a higher mortality in C. arabica. The developmental period and the number of eggs were not influenced by food substrates (Table 2).

\subsection{Olfactometry}

About $30 \%$ of nymphs of both species of mealybugs showed no response to odors $(n=60)$. Both mealybug species did not discriminate volatiles from Conilon and Mundo Novo (Table 3, Figure 2).

The nymphs of the two species of mealybugs showed no olfactory preference for the tested coffee species. Thus, odors do not seem to be important in host selection. Under field conditions, mealybugs do not face a choice situation due to their limited mobility, thus olfactory stimuli are not supposed to be relevant in host selection.

Host quality could only be identified after plant degustation, that is, after sap ingestion, which was verified through the free choice test. The free choice test primarily indicates the condition of the feeding site, namely phloem sap quality, stimulating moving or remaining on the feeding site. Even if a plant is accepted as a host in a preference test, $C$. canephora in this study, it does not mean a complete suitability of the plant for colonization. The nutritional characteristics of the plant may not be totally favorable for reproduction (Le Rü et al., 1995), restricting the size of the colony. 
Table 2: Biological parameters of Planococcus minor on leaves of coffee species $\left(25 \pm 1^{\circ} \mathrm{C}, 70 \pm 10 \% \mathrm{RH}\right.$, total scotophase $)$.

\begin{tabular}{cccc}
\hline Hosts & Nymph mortality (\%) & Female nymph period (days) & Number of viable eggs/fertile female \\
\hline \multirow{2}{*}{ Coffea arabica cv. Mundo Novo } & $90.0 \mathrm{~A}$ & $28.6 \pm 0.7 \mathrm{~A}$ & $142.8 \pm 18.4 \mathrm{~A}$ \\
$(\mathrm{n}=50)$ & $(\mathrm{n}=5)$ & $168.9 \pm 18.8 \mathrm{~A}$ \\
Coffea canephora cv. Conilon & $\begin{array}{c}28.5 \mathrm{~B} \\
(\mathrm{n}=47)\end{array}$ & $(\mathrm{n}=11)$ & 0.412 \\
\hline p value & 0.044 & 0.951 & $(\mathrm{n}=11)$ \\
& $\left(\chi^{2}\right)$ & (Student) & (Student) \\
\hline
\end{tabular}

Means followed by different letters in columns differ from each other by the $\chi^{2}$ test and Student test. $\mathrm{n}=$ number of observed insects.

Table 3: Final choice of $1^{\text {st }}$ instar nymphs of Planococcus citri and Planococcus minor submitted to the olfactometry test $(\mathrm{n}=30)$.

\begin{tabular}{ccccc}
\hline \multirow{2}{*}{ Insect } & \multicolumn{3}{c}{ Olfactory Response } \\
\cline { 2 - 5 } & $\begin{array}{c}\text { Coffea canephora } \\
\text { (arms 1 and 3) }\end{array}$ & $\begin{array}{c}\text { Coffea arabica } \\
\text { (arms 2 and 4) }\end{array}$ & $\begin{array}{c}\text { Absence of } \\
\text { Response }\end{array}$ & $\chi^{2}$ Test \\
\hline Planococcus citri & 9 & 10 & $11(36.7 \%)$ & $0.06 \mathrm{~ns}$ \\
Planococcus minor & 9 & 14 & $7(23.3 \%)$ & $1.08 \mathrm{~ns}$ \\
\hline
\end{tabular}

$\mathrm{ns}=$ not significant.

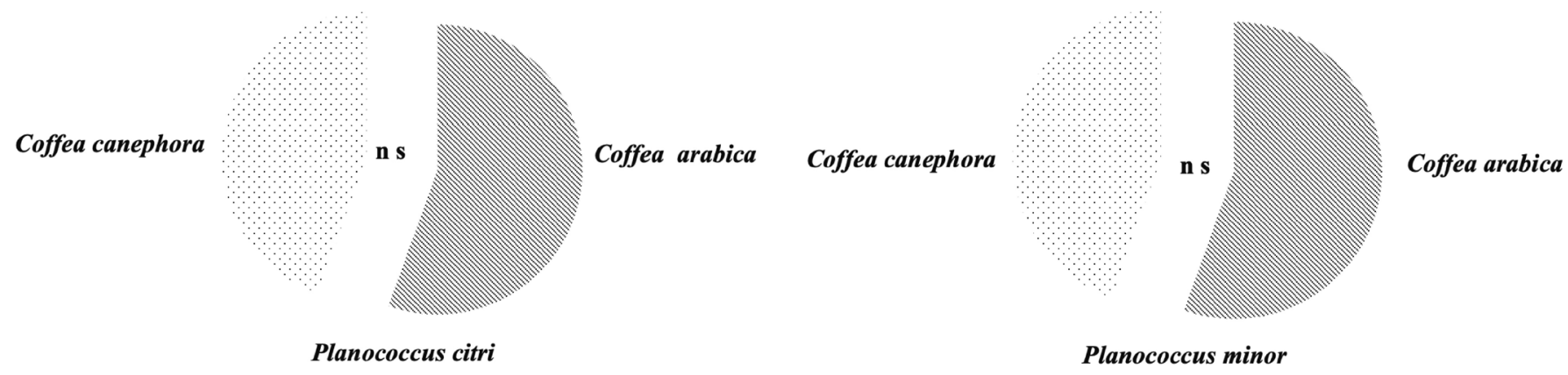

Figure 2: Relative permanence (\%) of $1^{\text {st }}$ instar nymphs of Planococcus citri and Planococcus minor in olfactometry test (Student values $p=0.4559, n=20$ and $p=0.4117, n=24$, respectively). Data analyzed with arcsine transformation $\sqrt{ } / 100, n=$ number of insects that responded to odors.

Development and reproduction were favored in Conilon coffee, agreeing with the results obtained in the free choice test. These results indicate that, in this plant, mealybugs are capable of forming larger colonies, which seems to agree with a situation found in the field.

It can be inferred that Conilon coffee shows greater adaptive value for these mealybugs, producing lower mortality in both mealybug species.

Although $P$. citri and $P$. minor have been registered for some years in Brazilian coffee growing (Von Ihering, 1897; Williams; Granara de Willink, 1992) are restricted the researches on the biology of these species in cultivars of coffee $C$. canephora cultivated under Brazilian conditions. Santa-Cecília et al. (2009) evaluated some biological aspects of the nymphal phase of $P$. citri in $C$. canephora cultivars, however, research showing aspects related to reproduction in these coffee plants is unknown for both scale insects. Thus, the discussion of the results obtained in the present study is limited in view of the scarce existing literature.

In C. arabica, several researches on the development and reproduction of these insects were carried out in Brazil (Correa et al., 2011; Santa-Cecília et al., 2009; 2018; SantaCecília; Prado; Oliveira, 2013; Sousa et al., 2012; 2018; Costa et al., 2016). Different periods of development and reproduction of both mealybug species in these coffee plants are found in these literature but laboratory results are difficult to compare due to different experimental conditions, manipulation and above all, the host plant and the plant organ used.

Dissimilar biological performance among coffee species explains why mealybugs are found more frequently and in higher populations in C. canephora. These results are important, mainly because they are mealybugs species involved in pest control programs in coffee crops and 
for contributing to a better understanding of mealybugs and coffee plant species interactions. In addition, this information consequently contributes to increase knowledge in the area of entomology and integrated management of coffee pests.

\section{CONCLUSIONS}

- Planococcus citri and P. minor show preference between coffee species presenting higher population growth potential in C. canephora cv. Conilon 213.

- Planococcus citri and P. minor do not discriminate odors emitted by $C$. canephora cv. Conilon 213 and C. arabica Mundo Novo-IAC 379-19.

\section{ACKNOWLEDGEMENTS}

To the Consortium of Coffee Research for the grant and financial support of this research. Thanks are extended to Mr. Ernesto Prado for revision of this manuscript.

\section{REFERENCES}

AMARASEKARE, K. G. et al. Life History of Paracoccus marginatus (Hemiptera: Pseudococcidae) on four host plant species under laboratory conditions. Environmental Entomology, 37(3):630-635, 2008.

AWMACK; C. S.; LEATHER. S. R. Host plant quality and fecundity in herbivorous insects. Annual Review of Entomology, 47:817-844, 2002.

CORREA, L. R. B.; SOUZA, B.; SANTA-CECÍLIA, L. V. C. Desenvolvimento da cochonilha-branca Planococcus citri (Risso, 1813) (Hemiptera: Pseudococcidae) em fruteiras. Arquivos do Instituto Biológico, 75(2):239-242, 2008.

CORREA, L. R. B. et al. Estudos biológicos de cochonilhas do gênero Planococcus (Hemiptera: Pseudococcidae) em diferentes hospedeiros. Arquivos do Instituto Biológico, 78(2):233-240, 2011.

COSTA, M. B. et al. Tabela de vida de Planococcus citri (Risso) e Planococcus minor (Maskell) (Hemiptera: Pseudococcidae) em cafeeiros. Coffee Science, 11(2):204-210, 2016.

GARCÍA MORALES, M. et al. ScaleNet: A literature-based model of scale insect biology and systematics. Database, 2016. Available in: <https://www.ncbi.nlm.nih.gov/pmc/ articles/PMC4747323/>. Access in: April, 27, 2020.

LEPAGE, H. S. Abóboras, cobaias para o estudo das pragas dos vegetais. O Biológico, 8(9):221-224, 1942.
LE RÜ, B. et al. Antennal sensilla and their possible meaning in the host-plant selection behavior of Phenacoccus manihoti Matile-Ferrero. International Journal of Insect Morphology and Embryology, 24:375-389, 1995.

PARRA, J. R. P. Consumo e utilização de alimentos por insetos. In: PANIZZI, A. R.; PARRA, J. R. P. Ecologia nutricional de insetos e suas implicações no manejo de pragas. São Paulo: Manole. p.9-65, 1991.

QIN, Z. et al. Effects of host plant on the development, survivorship and reproduction of Dysmicoccus neobrevipes Beardsley (Hemiptera: Pseudococcidae). Crop Protection, 30(9):1124-1128, 2011.

RENARD, S. Sensorial equipment and effect of the hostplant on the fixation behaviour of the cassava mealybug Phenacoccus manihoti Matile-Ferrero (Homoptera: Pseudococcidae). Belgian Journal of Zoology, 123(123):61-62, 1993.

SANTA-CECÍLIA, L. V. C. et al. Desenvolvimento de Planococcus citri (Risso, 1813) (Hemiptera: Pseudococcidae) em cafeeiros. Acta Scientiarum Agronomy, 31(1):13-15, 2009.

SANTA-CECÍLIA, L. V. C.; PRADO, E.; OLIVEIRA, M. S. Sobre o condicionamento alimentar na cochonilha-branca, Planococcus citri (Risso) (Hemiptera: Pseudococcidae). Revista Brasileira de Fruticultura, 35(1):86-92, 2013.

SANTA-CECÍLIA, L. V. C.; SOUZA, B. Cochonilhasfarinhentas de maior ocorrência em cafeeiros no Brasil. Informe Agropecuário, 35:45-54, 2014.

SANTA-CECÍLIA, L. V. C.; PRADO, E.; SOUZA, B. Probing behavior of Dysmicoccus brevipes mealybug in pineapple plants. Pesquisa Agropecuária Tropical, 46(4):458-463, 2016.

SANTA-CECÍLIA, L. V. C. et al. Potential of mealybugs infestation, Planococcus spp. (Hemiptera: Pseudococcidae), in an agroforestry system in coffee crops. International Journal of Environmental \& Agriculture Research - IJOEAR, 4(7):1-9, 2018.

SANTA-CECÍLIA, L. V. C. et al. Cochonilhas do cafeeiro no Brasil e seus inimigos naturais: uma síntese. Belo Horizonte: EPAMIG, 2020, 72p.

SILVEIRA-NETO, S. et al. Manual de Ecologia dos insetos. São Paulo: Agronômica Ceres, 1976, 419p.

SLANSKY, F. JR.; RODRIGUEZ, J. G. Nutritional ecology of insects, mites, spiders and related invertebrates. New York: J. Willey, 1987, 955p. 
SOUSA, A. L. V. et al. Especificidade alimentar: Em busca de um caráter taxonômico para a diferenciação de duas espécies crípticas de cochonilhas do gênero Planococcus (Hemiptera: Pseudococcidae). Revista Brasileira de Fruticultura, 34(3):744-749, 2012.

SOUSA, A. L. V. et al. Host preference and biology of two cryptic species, Planococcus citri (Risso) and Planococcus minor (Maskell) (Hemiptera: Pseudococcidae). Revista Scientia Agraria, 19(2):71-77, 2018.

TANGA, C. M. et al. Effect of six host plant species on the life history and population growth parameters of
Rastrococcus iceryoides (Hemiptera: Pseudococcidae). Florida Entomologist, 96(3):1030-1041, 2013.

VET, L. E. M. et al. An airflow olfactometer for measuring olfactory responses of hymenopterous parasitoids and other small insects. Physiological Entomology, 8(1):97$106,1983$.

VON IHERING, H. Piolhos vegetaes (Phytophthires) do Brazil. Revista do Museu Paulista, 2:385-420, 1897.

WILLIAMS, D. J.; GRANARA DE WILLINK, M. C. Mealybug of Central and South America. Walingford: CABI, 1992, 635p. 